\title{
Simplified Business Model
}

\author{
Mohammed R. Ahmed ${ }^{1}$ \\ ${ }^{1}$ School of Business, Webster University, St. Louis, Missouri, USA \\ Correspondence: Mohammed R. Ahmed, School of Business, Webster University, St. Louis, Missouri, USA. \\ Received: February 4, 2021 \\ Accepted: March 25, $2021 \quad$ Online Published: April 1, 2021 \\ doi:10.5430/ijba.v12n3p36 \\ URL: https://doi.org/10.5430/ijba.v12n3p36
}

\begin{abstract}
The purpose of this paper is to introduce the concept of business model to small, medium, and as well to large businesses in a simple framework. The paper presents the conceptual framework for the business model grounded with the quantitative business model that emphasizes profit motives. The quantitative business model, which has been in existence from the inception of business and commerce, refers to revenues minus costs and expenses equal to profits. The business model is created with the understanding of the quantitative model that is, and it shows how revenues are generated, profits are made, and costs are managed. The paper presents a simplified framework for developing a business model in a three-step process. In the three-step process for creating a business model, all participants' profit motives are considered critical for the success of the business process. The simple procedure for creating a business model presented in the paper would help both small and large businesses improve the business model creation processes to generate more value for both the customers and the companies.
\end{abstract}

Keywords: business model, small businesses, profit motives, three steps approach

\section{Introduction}

According to the U.S. Small Business Administration (2020) data, approximately 90 percent of the total businesses in the U.S. are small businesses. Additionally, it is also reported that approximately five out of ten small businesses fail in the first five years. One of the reasons for the failure among small businesses is the lack of adequate cash flows. A sufficient understanding of the business model may help small businesses in developing strategies to generate revenues, manage costs, and ultimately generate positive cash flows. It should be noted that the failure of small businesses in this respect is not just a problem in the U.S.; in reality, it is a global problem. There are millions of small businesses worldwide that could benefit from a better understanding of the business model so that they can succeed in the global marketplace. A clearer and simpler process for designing a business model would help both small and large businesses worldwide improve the processes involved in developing their businesses to generate more value for both the customers and the companies. It will also help individual investors make more rational decisions based on a substantial level of understanding with respect to the businesses they are interested in.

Managers or owner-operators are always interested in understanding the process involved in generating profits for their businesses. The company's business model can explain this process. The quantitative business model, which has been in existence from the inception of trade and commerce, refers to revenues minus costs and expenses, with what remains equivalent to profits. The researcher's encounters with owner-operators, managers, and investors worldwide found that most of them are familiar with the quantitative business model.

\section{What Is a Business Model?}

There is no clear definition of the business model in the research or business community. The term "business model" is currently used to describe the various elements of business processes, including strategy. According to Osterwalder et al. (2005), the term was first used in the academic literature in 1957 (Bellman, et al., 1957). Researchers in the past have presented a variety of definitions and explanations of the business model (Magretta, 2002; Hamel, 2000; Chesbrough \& Rosenbloom, 2002; Chesbrough, 2006; Johnson, et al., 2008; Zott \& Amit, 2010; Teece, 2010; Chatterjee, 2013). There is no universally accepted definition that researchers agree on to explain of the business model. The term is generally used for identifying several business processes and strategies. The paper aims to identify simple steps involved in developing a business model using the primary reason for the existence of the business. Businesses exist to make profits, and all the participants in business have a profit motive. This approach is slightly different from the explanation of the business model by the researchers in the past. The three variables in the models are revenues, 
costs, and profits because the variables are critical for the company's survival, profits, and growth. Businesses should build the business model using the three variables of the quantitative business model.

Table 1. Quantitative business model

Revenues minus Costs equals Profits

In this paper, "business model" is defined as a design for solving customer problems and achieving the organization's goals. The goal of an organization is to minimize costs and maximize the long-term profits or wealth of the organization. While the term "business model" may have first appeared in the academic literature in 1957, the newspaper industry introduced the concept of the business model during the 17th century. An analysis of newspaper businesses from the 1700s will help illustrate that business models are designed or developed to create business opportunities. While newspaper businesses did not use the label of business model in describing the design of their business processes, they were concerned with how to generate revenue, manage costs, and generate profits.

The businesses were aware that the general public is the customer for information consumption. There was demand for newspaper services, but the customer could not pay the cost-plus-profit price for the newspaper because of their limited disposable income. At the same time, the newspapers could not print paper at an affordable cost for the customers. To create an opportunity for newspaper businesses, they explored alternative ways to generate revenue. A new business model was developed to offer consumers the newspaper at an affordable price and focus on revenue, costs, and profits. They realized that the individual business cost of communicating with the customer was very high. Thus, they provided advertising space in the newspapers at a reduced cost for promoting products and services. The new model was developed to generate revenue from advertisers to make the newspaper affordable to the consumers. Lowering prices increased the circulation of the papers and the market coverage for the advertisers. An increase in circulation generated growth in the company's revenues, reduced the unit cost of the newspaper as a result of the spread of fixed costs, and increased the profits of the company. This model, which includes generating revenue, managing costs, and generating profits, is a business model. All the parties involved in the business transaction have profit motives and benefit from the business model. A business model is designed and developed to fulfill all the participants' profit motives in the business transaction. Business models should be designed based on the basic quantitative business model that states that revenue minus costs equals profits. This is because businesses are formed to generate long-term profits or wealth for the owners of the company.

\section{Why Business Model?}

The primary goal of businesses is to make long-term profits by offering products or services that effectively target potential customers. In other words, businesses create products or deliver services to solve the customers' problems. A good example is a restaurant providing services to solve problems of hunger or cravings and to provide a venue for satisfying dining experiences. Businesses are continually looking for creative and innovative ways to solve customers' issues and motivate them to buy products or utilize their services. Most of the time, businesses have to go beyond merely solving problems and offer innovative solutions that are considered exceptional value. The value is generated by creatively solving the customer's problem and satisfying the customer's cost objectives and profit motives. At the same time, the businesses' value must be profitable so that they can continue to provide the desired products and services to their customers and stay in business at the same time.

The business model shows how revenues are generated, profits are calculated, and costs are managed. There is a lot of discussion in the business research community about the importance of this model in helping businesses to obtain competitive advantages in the marketplace by generating long-term profits. These discussions have not yet produced a simple approach that could use in understanding the revenue, cost, and profit relationship in the business development process. Small and medium-sized business owners and managers worldwide have difficulty understanding and implementing the business model successfully. Furthermore, the average investor also has difficulty understanding this particular business model before buying into a specific company. An understanding of the business model will help the businesses and investors in making profitable decisions.

\section{Simplified Business Model}

A simplified business model (qualitative or conceptual) can provide an explanation of the business process, whereas a quantitative business model can help to determine the performance of the company. The development of the simplified business model starts with three basic questions based on the quantitative business model: (1) How will revenues be 
generated? (2) How will the costs and expenses be managed? (3) How will profits be generated? The process for developing a business model is the same for small, medium, and large-sized businesses. The simplified framework presented for developing a business model in this article involves a three-step process. The profit motives of the participants in the business are considered in each step to ensure the business model's success. The profit motives in the model include monetary, psychological, and social profits.

\subsection{Psychological Profits}

Psychological profits are the benefits gained by the customer when using one company's product or service over another's. These benefits to customers come in the form of a reduction of stress, an improvement in self-esteem, or just a general experience of positive emotions. As an example, consider the following situation involving Uber. I was staying in a metropolitan city at a brand name five-star hotel on business. I have stayed at this hotel for the past two decades, and I have seen taxis in the parking lot almost all of the time. On one particular occasion, I had an early meeting on Saturday morning at 8:00 AM. I came down to the parking lot of the hotel and got into my car, but it would not start. I immediately began looking for a taxi, but I did not see any at the hotel that morning. I asked the bell person to call a taxi for me, but I was informed that the taxi could take 25 minutes to get to the hotel. It was around 7:15 AM, and I was concerned that I would be late for the meeting. I was quite stressed out by this incident. All of sudden, Uber came to my mind, likely because I had recently been discussing their business model with my MBA learners. I googled Uber on my iPhone and downloaded the app. I entered my personal information, including my credit card number, and the total process probably only took about two or three minutes. All of a sudden, I saw my pinned location on the screen and little cars moving nearby. I pushed the button to request the service, and I saw an Uber driver's picture and the car navigating toward my location, along with an approximate time of arrival. At the same time, however, the concerned bell person was putting in extra effort to find another taxi that could be at the hotel in 10 minutes. I was thankful to the bell person for trying to help with my situation, but I asked him to cancel the taxi because of the psychological profit of going with Uber instead. I could see the Uber car driving toward my location, and I did not see the taxi that the bell person promised was on the way. My stress level immediately lowered, and I began to feel more positive emotions. This is a good example of the psychological profit motive from the perspective of the customers.

\subsection{Social Profit Motives}

As individuals, we are interested in personal and social profits because we are human beings who are concerned for ourselves and each other. We are also interested in social gains because they may eventually be of benefit to everyone in a given society. The social profits in relation to the business model are the benefits incurred by the community or the society due to the customer's decision to use one company's products or services over another's because of the company's commitment to delivering such social profits. The concern may involve the wellbeing of the people, the protection of the environment, or quite simply anything else that benefits the community, society, or the environment in some way. Consider the following example as an illustration. I have visited China several times, and when I opened the curtains of the window one morning at my hotel in Beijing, it was very dark because of the smog. Whether I am living in Beijing or just visiting on business, as an individual I am concerned about the effects of the smog on society, and I will take action that will help in lowering the smog level, or in other words, that will generate social profits. As a result, if I needed local ground transportation service, I would select a company that is offering a ride share, electric car, or hybrid car service because of my social profit motive.

\section{How to Create a Business Model in Three Steps?}

The framework presented in this article is designed to simplify the business model creation process by providing an analysis of an existing business process. The framework divides the process into three steps based on the three questions: (1) How will the revenues be generated? (2) How will the costs and expenses be managed? (3) How will the profits be generated? In the three-step framework, creativity and innovation are needed for the revenue generation, cost management, and profit generation processes. In this framework, all of the functions of a business, such as marketing, financial operations, operational management, human resources, and technology, are critical for the success of the business process.

The proposed model includes the profit motive of all the participants to generate sustainable growth for the business. A sustainable growth approach to building a business model encourages the companies to be socially responsible and concerned about all the stakeholders in the business and industry. The following chart shows the three-step involve in creating a Business Model for a digital company connecting passengers to a vehicle owner-operator. 
Table 2. Three-step business model

\begin{tabular}{|c|c|c|c|c|}
\hline \multirow{3}{*}{1.} & \multirow{3}{*}{$\begin{array}{l}\text { Revenues: } \\
\text { How would you } \\
\text { generate } \\
\text { revenues? }\end{array}$} & \multicolumn{3}{|l|}{ Creativity and Innovation } \\
\hline & & $\begin{array}{l}\text { Identify the target customers } \\
\text { and the problem that the } \\
\text { company is planning to } \\
\text { solve. }\end{array}$ & $\begin{array}{l}\text { Identify the profit motives } \\
\text { of the target customers. }\end{array}$ & $\begin{array}{l}\text { Explain how the } \\
\text { revenues } \\
\text { generated. }\end{array}$ \\
\hline & & $\begin{array}{l}\text { Provide transportation } \\
\text { services to people who are } \\
\text { traveling, do not own cars, } \\
\text { do not drive, do not like to } \\
\text { drive, or are looking for an } \\
\text { alternative to rental cars or } \\
\text { taxis. }\end{array}$ & $\begin{array}{l}\text { Saving time and money, } \\
\text { easy access, convenience, } \\
\text { comfort, safety, and } \\
\text { reduction of pollution } \\
\text { while utilizing } \\
\text { transportation services. }\end{array}$ & $\begin{array}{l}\text { Matching users on } \\
\text { demand with car } \\
\text { owners interested in } \\
\text { providing } \\
\text { transportation services. }\end{array}$ \\
\hline \multirow[t]{2}{*}{2.} & \multirow{2}{*}{$\begin{array}{l}\text { Costs } \\
\text { Expenses: } \\
\text { How would you } \\
\text { manage costs and } \\
\text { expenses? }\end{array}$} & $\begin{array}{l}\text { Identify the resources needed } \\
\text { to solve the customers' } \\
\text { problems. }\end{array}$ & $\begin{array}{l}\text { Identify the profit motives } \\
\text { of the participants needed } \\
\text { to solve the customers' } \\
\text { problems. }\end{array}$ & $\begin{array}{l}\text { Explain how the costs } \\
\text { and expenses will be } \\
\text { managed. }\end{array}$ \\
\hline & & $\begin{array}{l}\text { Car owner } \begin{array}{r}\text { operators, } \\
\text { on-demand }\end{array} \begin{array}{l}\text { matching } \\
\text { service, } \\
\text { payment }\end{array} \text { pricing, management } \\
\text { systems. }\end{array}$ & $\begin{array}{l}\text { Generate income, practice } \\
\text { sound entrepreneurship, } \\
\text { ensure safety and provide } \\
\text { the opportunity to generate } \\
\text { income with existing } \\
\text { assets. }\end{array}$ & $\begin{array}{l}\text { Using the unused } \\
\text { capacity of the car } \\
\text { owner operators, } \\
\text { efficient pricing, and } \\
\text { payment management } \\
\text { systems. }\end{array}$ \\
\hline \multirow[t]{2}{*}{3.} & \multirow[t]{2}{*}{$\begin{array}{l}\text { Profits: } \\
\text { How would you } \\
\text { generate profits? }\end{array}$} & $\begin{array}{l}\text { Identify the relationship } \\
\text { between revenues and } \\
\text { costs/expenses. }\end{array}$ & $\begin{array}{l}\text { Identify the profit motive } \\
\text { of the company. }\end{array}$ & $\begin{array}{l}\text { Explain how the profits } \\
\text { will be generated. }\end{array}$ \\
\hline & & $\begin{array}{l}\text { Fixed proportion of } \\
\text { revenues, cost is a function } \\
\text { of the market size, and } \\
\text { expenses are based on } \\
\text { volume. }\end{array}$ & $\begin{array}{l}\text { To survive long-term and } \\
\text { explore the potential } \\
\text { growth opportunities for } \\
\text { creating wealth in the } \\
\text { future. }\end{array}$ & $\begin{array}{l}\text { Sharing a fixed } \\
\text { proportion of revenues, } \\
\text { maintaining scalable } \\
\text { fixed costs, and } \\
\text { calculating expenses } \\
\text { based on volume. }\end{array}$ \\
\hline
\end{tabular}

In the above model, the assumption is that the start-up is interested in competing with the taxi service segment of the transportation industry by offering an alternative solution to customers. The following are the further explanation of three steps for creating the business model.

\subsection{First Step Revenue Generation}

The first step in the revenue generation process is to identify the target customers and the current solutions offered to the customers' problem. The target customers in this case are people who are traveling on public transportation, do not own cars, do not drive, do not like to drive, or are looking for an alternative to car rentals or taxis. The customer's solution is ground transportation of some sort. The second step is to identify the profit motive of the customers. The profit motives of the customers are saving time, lowering costs, easy access, convenience, comfort, safety, and reduction of environmental pollution. The third step involves explaining how the revenues are generated. The company will generate revenues by matching users on demand with car owners interested in providing transportation services. This is the best alternative for generating revenues because of the minimal barriers for entering the market, a much lower investment compared to starting a taxi company, the millions of customers needing alternative transportation services, and the millions of car owners interested in offering alternative transportation services. 


\subsection{Second Step Cost Management}

The first part of the cost management process involves identifying the resources needed for solving the customers' problem. The resources needed in this case are car owner operators, an on-demand matching service, appropriate pricing, and payment management systems. The second step is to identify the profit motives of the participants involved in solving the problems. The owner operators' profit motives are to generate income, experience entrepreneurship, ensure safety, and generate income with existing assets. The third step is to explain how the cost will be managed. In this case, the company will use owner operators who have unused capacity to deliver the service, efficient pricing, easy payment systems, low operating costs, and an expense management system. The unused capacity is a loss to the car owners, and the profit motives for being a vehicle owner operator will help the company to attract more car owner operators, keeping the cost of the service low. This will be an effective cost management strategy for maintaining a lower fixed cost and offering competitive prices in the marketplace.

\subsection{Thrid Step Profit Generation}

The start of the profit generation process involves identifying the relationship between revenues, costs, and profits. The revenues are a fixed proportion of revenues generated by the car owner operators. The cost is a function of the market size, and expenses are based on the volume. The second step is to identify the profit motive of the business. The profit motive of the company is to break-even and survive long enough to prove to investors that the business model is working, and that there is potential for future profits and growth. The third step is to explain how the profits are generated. In this case, the company will share a fixed proportion of the revenues from the owner operators, maintaining scalable fixed costs and managing expenses based on volume. The scalable fixed costs and expenses based on volume will be kept down and increase the profit margin. This will allow the company to expand globally with minimum investment with or without breaking even first.

\section{Conclusion}

In conclusion, the process involved in generating profits for a business is best understood by creating a simplified business model. The creation of a profitable business model involves an understanding of the customers' problems, the ability to develop creative and innovative solutions, the acquisition of the required resources, and an understanding of the profit motives of the customers, suppliers, and businesses. Once the business model is created for the company, all of the functional strategies are formulated using the business model as a guide and implemented to make the business process successful in the marketplace.

For example, marketing strategies are used for creating shared value, pricing, advertising, promotion, and branding. Financial and accounting strategies are used to manage and control costs and expenses. Operational strategies are used for producing and delivering quality products and services. Human resource strategies are used for training, motivating, and offering fair compensation for employees. Technology is used in all of the functional areas, including marketing, finance, operations, and human resource management, to create a competitive advantage in the marketplace. It is important to realize that the business model is not a static model; it is a dynamic model. Management has to monitor the changes in the profit motives of the participants in addition to the environment surrounding the business in order to effectively adjust the business model for continued success in the marketplace.

Successful companies such as Apple, Google, Uber, and Facebook are good examples of how an effective business model incorporates the profit motives of the participants of the business. The three-step framework will be helpful for creating a business model, analyzing an existing model, or in formulating a particular business strategy. Furthermore, the framework is practical because the performance of the model could be easily measured using the more complex quantitative business model.

\section{References}

Afuah, A. (2004). Business models e a strategic management approach. Mc Graw Hill Irwin, New York.

Bellman, R., Clark, C. E., Malcolm, D. G., Craft, C. J., \& Ricciardi, F. M. (1957). On the construction of a multi-stage, multi-person business game. Operations Research, 5(4), 469-503. https://doi.org/10.1287/opre.5.4.469

Chesbrough, H. (2006). Open business models. Harvard Business Review Press, Massachusetts.

Chesbrough, H., \& Rosenbloom, R. S. (2002). The role of the business model in capturing value from innovation: evidence from xerox corporation's technology spin-off companies. Industrial and Corporate Change, 11(3), 529-555. https://doi.org/10.1093/icc/11.3.529

Hamel, G. (2000). Leading the revolution. Boston, Mass.: Harvard Business School Press. 
Johnson, M. W., Christensen, C. M., \& Kagermann, H. (2008). Reinventing your business model. Harvard Business Review, 86(12), 50-59.

Magretta, J. (2002). Why business models matter. Harvard Business Review, 80(5), 86-92.

Osterwalder, A., Pigneur, Y., \& Tucci, C. (2005). Clarifying business models: origins, present, and future of the concept. Communications of the Association for Information Systems, 16, 1-25. https://doi.org/10.17705/1CAIS.01601

Teece, D. J. (2010). Business models, business strategy and innovation. Long Range Planning, 43(2-3), 172-194. https://doi.org/10.1016/j.lrp.2009.07.003

U.S. Small Business Adminstration. (2020). Office of adocacy. Retrieved from http://advocacy.sba.gov

Zott, C., \& Amit, R. (2010). Business model design: an activity system perspective. Long Range Planning, 43(2-3), 216-226. https://doi.org/10.1016/j.lrp.2009.07.004

\section{Copyrights}

Copyright for this article is retained by the author(s), with first publication rights granted to the journal.

This is an open-access article distributed under the terms and conditions of the Creative Commons Attribution license (http://creativecommons.org/licenses/by/4.0/). 